Journal of Sustainable Development of Transport and Logistics

journal home page: https://jsdtl.sciview.net

Dragomir, C., \& Lau, Y.-Y. (2018). Investigating the next generation of managers - the

ecomanagers. Journal of Sustainable Development of Transport and Logistics, 3(2), 82-90.

doi:10.14254/jsdtl.2018.3-2.6.

\title{
Investigating the next generation of managers - the ecomanagers
}

\section{Cristina Dragomir ${ }^{1}$ (D), Yui-yip Lau ${ }^{2}$}

${ }^{1}$ Faculty of Navigation and Naval Transport, Department of Management in Transports, Constanta Maritime University, Str. Mircea cel Bătrân 104, Constanța, 900663, Romania

${ }_{2}^{2}$ Division of Business, Hong Kong Community College, The Hong Kong Polytechnic University

9 Hoi Ting Road, Yau Ma Tei, Kowloon, Hong Kong

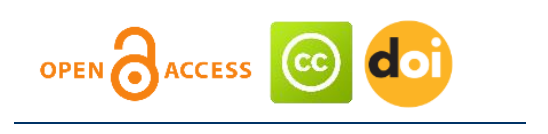

\section{Article history:}

Received: July 26, 2018

1st Revision: August 16, 2018

Accepted: October 25, 2018

\section{DOI:}

10.14254/jsdtl.2018.3-2.6

\begin{abstract}
The next generation of managers emerges as a consequence of the environmental changes that affect the world economies. In this paper is presented the profile of the new type of manager adjusted to the current world trends: the ecomanager. While ecomanagement refers to strategies implemented to minimize or eliminate the adverse effects of human activities on the environment, ecomanagers are those develop and implement environmental policies in all the management activities and in the entire workflow of the organization. In this paper is presented an example of implementing ecomanagement in a Korean shipping company and there are presented specific ecomanagement strategies and actions regarding both onshore and offshore activities.
\end{abstract}

Keywords: management, sustainable development, environment, shipping, ecomanager, ecomanagement.

\section{Introduction}

\section{Economic Context: Environmental Changes.}

For over 300 years, the world is in a new era without realizing. The industrial revolution occurred in the middle of the 1700s. Industrialization is described as "the process of transformational change of the human socially and economically from an agrarian society into an industrial one" (Mgbemene et al., 2016, pp. 302). Industrialization definitive changed Earth's geological properties. The global footprint that influenced the environment and the knowledge revolution led, indirectly, to massive changes of the consumption behavior. British geologists consider that we have passed from the Holocene epoch that lasted 10,000 years. In 2002, Nobel winner chemist Paul Crutzen suggested for the first time that people have left the Holocene to Anthropocene, the current geological epoch, where humankind have a central role in the environment. How has industrialization affected the environment in the next generation?

Corresponding author: Yui-yip Lau

E-mail: yylau@hkcc-polyu.edu.hk 
According to Paul Crutzen, during the past three centuries human population increased tenfold to more than 6,000 million. Industries increased more than 40 times and energy use more than 16 times. A percentage of 30$50 \%$ of the world's land surface has been transformed by humans. Agricultural land has doubled during the past century at the expense of forests. In a few generations mankind will run out the fossil resources that were generated in hundreds of millions of years. As a result of increasing fossil fuel and coal burning, agricultural activities, deforestation, and intensive animal husbandry, several climatically important greenhouse gases have substantially increased in the atmosphere over the past three centuries. Humankind also releases detrimental substances that are not directly toxic, but which destroy stratospheric $\mathrm{O}_{3}$ and have led to the Antarctic ozone hole (Crutzen, 2011) and climate change. It is notable that climate change can be explained as the continual change in the weather pattern created by anthropogenic activities mostly associated with industrialization. The climate change clearly shows a significant change in climate normal in terms of average values for precipitation and temperature (Mgbemene et al., 2016). The climate change is an irreversible process which could give rise to catastrophic risks to human welfare (Yang et al., 2018). Birkman et al., (2010, pp. 188) highlight that "climate change impacts include multi-hazard phenomena, such as the simultaneous occurrence of sudden-onset hazards and creeping changes". The effects can be created dramatic changes in extreme weather patterns directly influence the Earth's flora, which come out affects animals and humans ( $\mathrm{Ng}$ et al., 2018). The negative consequences are dealing with higher temperatures, unprecedented flooding, rising sea levels, increasing ocean acidification and increasing in diseases (Mgbemene et al., 2016).

Environmental changes have a great impact on the economic activity of enterprises and calls for a new kind of management, called ecomanagement. According to the American Heritage Dictionary of the English Language, "ecomanagement" term refers to any of various strategies to minimize or eliminate the adverse effects of human activities on the environment (The American Heritage Dictionary of the English Language, 2000). Ecomanagement requires a totally changed way of thinking business, from all the socio-economic points of view, applied to all the activities of a company. Like companies from other domain, they constantly monitor and analyze their environmental impacts and make corresponding efforts to reduce environmental burden of their day-to-day business activities (IEMA, 2018), ease the problem of infrastructure damage and repairs (Ng et al., 2018) and offer a quality service (Ng et al., 2016). The term sustainable development which stays at the basis of ecomanagement was popularized in Our Common Future, a report published by the World Commission on Environment and Development in 1987. Also known as the Brundtland report, Our Common Future included the classic definition of sustainable development: development which meets the needs of the present without compromising the ability of future generations to meet their needs (United Nations World Commission on Environment and Development, 1987). Acceptance of the report by the United Nations General Assembly gave the term political salience; and in 1992 leaders set out the principles of sustainable development at the United Nations Conference on Environment and Development in Rio de Janeiro, Brazil (Drexhage \& Murphy, 2010). The concept of sustainable development is widely discussed in various literatures (e.g., Boron \& Murray, 2004; Dasgupta, 1993; Dalal-Clayton \& Bass, 2002; Jackson \& Michaelis, 2003; Wang et al., 2017), to name but a few Environment and natural resources are capital that must be maintained in order to support sustained economic activity in a maritime industry. Protecting the environment thus preserves the very basis for development and is urgent demanded for a maritime industry (Năstase \& Popescu, 2007). Although notable progress has been created in terms of effective environmental management, with the consensus of the wider maritime industry, a majority of it is reactive and based on a control and command philosophy (WWF, 2012).

Maritime transport carries more than two-thirds of global cargoes and remarkably affects the world's economy. Shipping companies act key roles in supply chains, as they link between manufacturing plants and consumption areas across continents, which in turn foster the growth of national and regional economies. Climate change may generate economic losses to shipping companies, determining the regional economy, the lives of people in coastal cities and the operation of supply chains ( $\mathrm{Ng}$ et al., 2018). Shipping companies applying ecomanagement, invest in pro-environmental projects and implement environmental management systems, for example EMAS -Eco-Management and Audit Scheme, ISO 14001 and international regulations of IMO regarding the sustainable development. The Eco-Management and Audit Scheme (EMAS) is a voluntary initiative designed to improve the companies' environmental performance. It was initially established by European Regulation 1836/93. It is focused on those organisations that go beyond minimum legal compliance and continuously improve their environmental performance (International Organization for Standardization, 2018). Though shipping is one of the most efficient and environmentally benign modes of transport, a small number of shipping accidents have 
tarnished this image. Public awareness, pressure groups and legal directives have forced shipping companies to have a second look at their Environment Management practices and adopt ways to minimize pollution. Leading shipping companies are now beginning to seek ISO 14001 certification for their offices and for their ships. These companies are also rewarded with better business prospects and surprisingly even cost benefits (Wilhelmsen, 2018). The ISO 14000 certification standard provides practical tools for companies and organizations looking to identify and control their environmental impact and constantly improve their environmental performance. The benefits of using ISO 14001 can include reduced cost of waste management, savings in consumption of energy and materials, lower distribution costs and improved corporate image among regulators, customers and the public (Bojar, 2012).

Nevertheless, the next generation of managers appears as a result of the environmental changes that influence the world economies. In this paper, we address how the ecomanager develops efficient adaptation measures that manage the organization in response to the environment. The rest of the paper is structured as follows. Section 2 conducts the literature review about the new type of economy and the next generation of managers. Section 3 generates an illustrative example of implementing ecomanagement in a Korean shipping company which addresses specific ecomanagement strategies and actions concerning both onshore and offshore activities. Finally, the conclusion can be found in Section 4.

\section{Literature Review}

\section{The New Type of Economy and the Next Generation of Managers}

The new type of manager of current times thinks and acts environmentally and takes into account the complexity of human-environment relationships by making decisions following long-term benefits that can be obtained in the context of today environmental changes. Managers who develop and implement environmental policies in all the activities of management and in the entire workflow of the organization can be called ecomanagers.

Ecomanagers are flexible enough to adapt to the new environment focusing on the objective of sustainable development. Their main feature is making decisions in accordance with the principles of sustainable development by identifying ways to obtain economic development in conditions of environmental protection. The shipping industry is not only closely associated with government policy and socio-economic, but also directly affects the ecological environment and resources (Wang et al., 2017).

Ecomanagers have as specific objectives adapting environmental data to business particularities, harmonization of environmental legislation, integrated environmental authorization, implementation of environmental management systems, making decisions regarding the use of green manufacturing, green packaging, eco-labeling, development of environmental projects, purchase of environmentally friendly technologies and development of skills necessary to use green technologies.

Ecomanagers goal is to minimise the amount of waste, reduce energy consumption and make more efficient use of resources in order to make cost minimization, besides protecting the environment.

In general, ecomanagers have a proactive attitude towards developing production, services and trade in accordance with the principles of sustainable development and for redesigning their business on the foundation of these principles. In the previous period, the main concern of managers was getting benefits regardless the environmental effects of means used. Therefore, were purchased technologies with good labor productivity on the expense of the environment, there were built factories, businesses and halls which were not complying with environmental specifications etc.

The concept of sustainable development aims to raise awareness on the effects that managers' decisions have on environment, decisions that will affect future generations. Ecomanagers choose those solutions that proves to be economical efficient without harming the environment. These solutions relate to reducing resource consumption; recycling; applying environmental standards and ISO certification; focusing on changing the mentality of employees and stakeholders by targeting sustainable development.

In a shipping company where ecomanagement is implemented, the Managing Director and directors of all the departments act according to the ecomanagement principles and coordination of the Ecomanagement Department until they become ecomanagers and the company start to accomplish the planned objectives of sustainable development on a daily basis and in an accustomed manner. 
Following is an example of organizational chart of a shipping company with Ecomanagement Department. The company represented below has outsourced the Legal Department and the Crewing Department to specialized companies. The novelty is that beside the ordinary departments like Chartering, Technical Department, Administrative Department, Finance and Accounting, stands out the Ecomanagement Department.

Chartering Manager is mainly deal with marketing and booking of cargo, allocation of space, responsibility for routing, documents, port facilities, loading/discharging, control of port expenses, stevedore contracts, etc. arrange employment for the vessels and are also responsible for their operation. He also handles chartering contracts for the company fleet.

Finance and Accounting Managers are responsible with budgets, accounting, EDP and operational department, each ship and for the shipping company as a whole. The General Manager keeps the Accounting manager up to date with operational proceedings at all times, with changes and corrections when necessary.

The Technical Managertakes care of fleet management, including ship operations, manning, storing, repair, maintenance and dockings. He is also responsible for building of new ships, often organized in a new-building section. He makes project development with optimization studies and operational analysis in cooperation with other departments, with the coordination of the Ecomanager.

The Administrative Manager is responsible for the main organization of the shipping company, for personnel, internal services and internal control.

The Ecomanager deals with implementing the environmental policies in the total management of the organization, coordinates and monitor the activity of all the other departments and sub-departments (that don't appear in the figure) in order to comply with the eco management policies.

\section{Figure 1. Organizational chart of a shipping company with Ecomanagement Department}

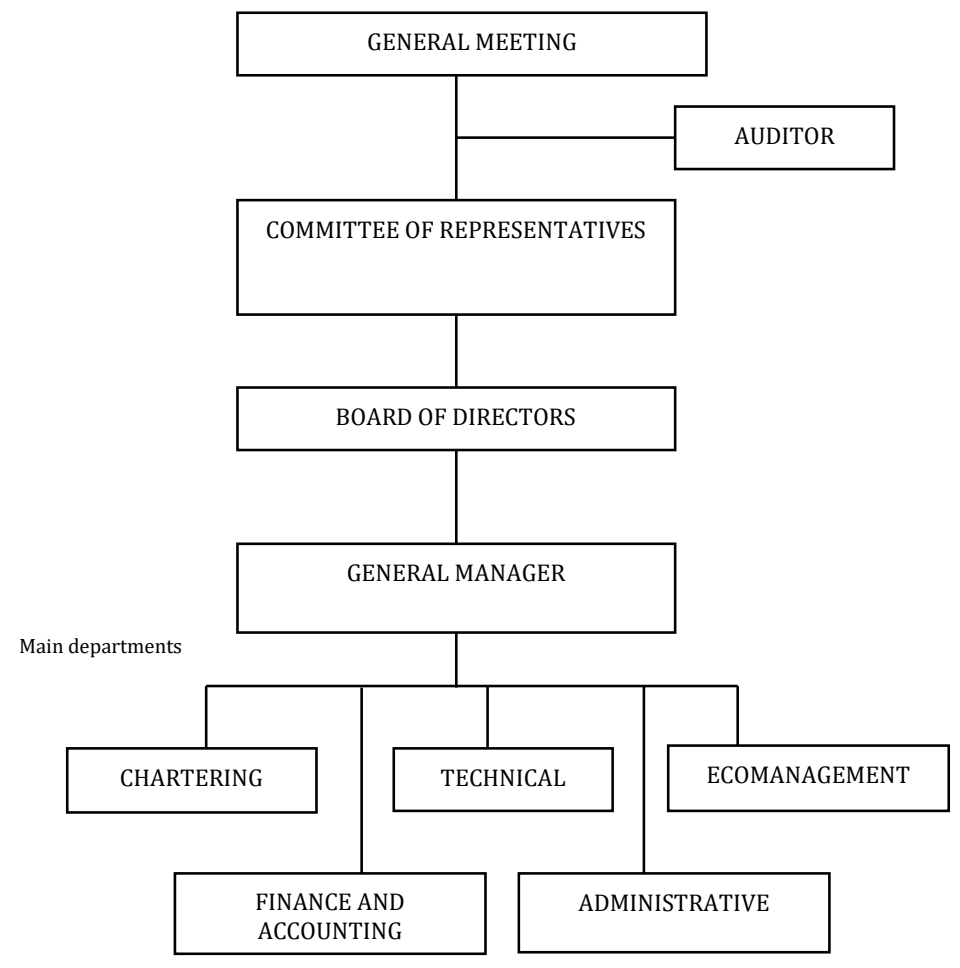

Shipping companies should be aiming at agility in their organizational development, as changing conditions in the world market might make it necessary to reorganize or set up new departments (Lau, 2018). If considered a high expense, the shipping company can renounce at the Ecomanagement Department after all the departments got accustomed to the ecomanagement and environmental policies and once the managers of the departments start to think and act as genuine ecomanagers in all types of onshore and offshore activities.

In the organization chart the interaction between the main department and the subdepartments is shown by lines of authority. This authority goes down from the shipowners, through the main departments and down into the organization. The lines show how the instructions for the company are transmitted from the shipowners through the different links, so without shipowners open to the ecomanagement scope and principles, the structure of a shipping company with eco managers cannot resist. All department heads are fully responsible for their own 
activities and they must therefore be fully familiar with all environmental matters concerning their departments so as to be capable of managing and making decisions (Pritchard, 2000).

In all the production process, ecomanagers limit the use of materials that are not environmental-friendly, as well as the amount of waste and pollutants resulting from technical processes. Ecomanagers limit the energy consumption and recommends employees to reduce to minimum the consumption of electricity, heat, water and resources. These actions have the effect of not only protecting the environment but also reducing the costs of the organization, influencing positively the profit obtained in the course of business.

\section{Hanjin Shipping: A Case Study of Ecomanagement in Maritime Business}

\subsection{Hanjin Shipping's Environmental Involvement}

Hanjin Shipping has been established in 1945. Hanjin Shipping is Korea's largest and one of the world's top ten container carriers that operates some 60 liner and tramp services around the globe transporting over 100 million tons of cargo annually. Its fleet consists of some 200 containerships, bulk and LNG carriers.

Hanjin Shipping, an operating company of Hanjin Shipping Holdings has its own subsidiaries dedicated to ocean transportation, terminal operation, ship management, ship repair and 3PL serving various customers around the world. With 6,000 employees in 60 different countries and 230 branch offices, Hanjin Shipping is building its global logistics network, which is also supported by the company's 13 dedicated terminals at the world's major hub ports and 6 inland logistics bases.

Hanjin Shipping provides advanced service in their eco-friendly vessels, world-class logistics IT system and automated terminals.

In a bid to address Climate Change issues, the 15th UN Climate Change Conference (COP15) held in 2009 called for member countries to curtail atmospheric $\mathrm{CO}^{2}$ emissions to less than $450 \mathrm{ppm}$ and for the increase of global temperatures to be no more than $2^{\circ} \mathrm{C}$ above preindustrial levels. Contrary to common belief, the global shipping industry is an eco-friendly form of transportation, accounting approximately for just over $2.7 \%$ of global $\mathrm{CO}^{2}$ emissions. Also, the World Ports Climate Declaration designed the World Ports Climate Initative address the climate change problem which promotes a close collaboration between the key port cities and shippiing companies (Ng et al., 2018). Conducting business in the ocean, Hanjin Shipping continuously looks for and implement various environmental management initiatives in order to mitigate climate change.

Hanjin Shipping's Environmental Safety Management System is in accordance to the ISO 14001. With its basis in environmental safety policies, all ships and departments establish and execute action plans in regards to executing, monitoring, reporting and revising for the more effective practice of environment management.

Hanjin Shipping declared their commitment to environmentally-friendly management, with environmental goals developed in line with environmental policies.

Figure 2: $\mathrm{CO}^{2}$ reduction ecomanagement activities applied by Hanjin Shipping

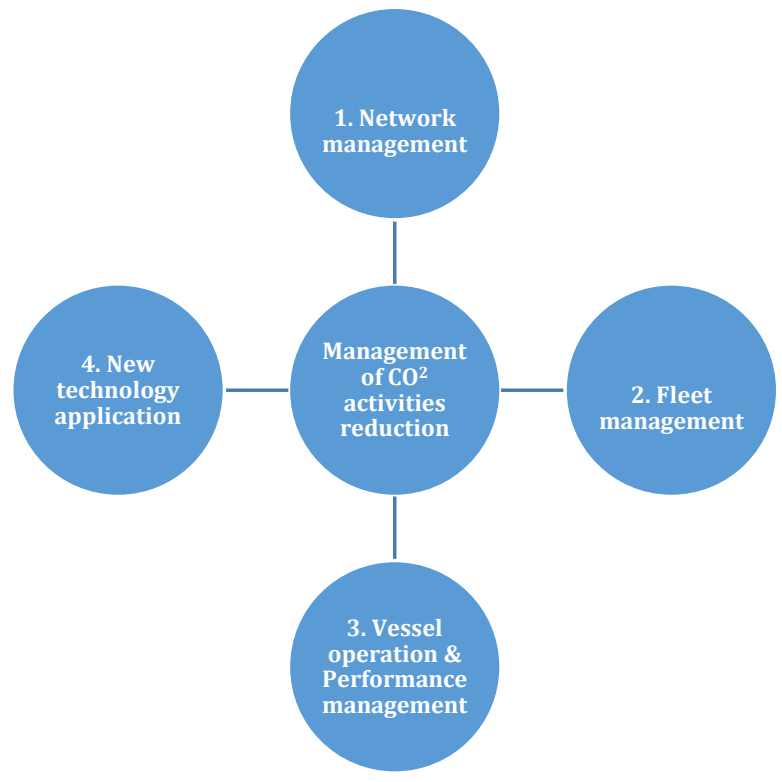


In addition, Hanjin Shipping adopted eco-friendly containers, developing their very own $\mathrm{CO}^{2}$ emission calculator and establishing management system based on ethics and transparency of global standards. Hanjin is reducing the ship waste by eliminating waste caused from damage to cargo and by reducing the discharge of sludge and waste oil. The use of natural resources is decreased by reducing the use of fuel oil, reducing the use of cylinder oil in main engines and reducing the use of engine system oil. Water pollutant emissions are reduced by using ecofriendly paint, applying ballast water control plans and eliminating marine spill accidents. Also, reducing greenhouse gas and air pollutant emissions are made by reducing the use of coolant, eliminating complaints regarding smoke and by introducing cutting-edge facilities in order to reduce hazardous atmospheric discharge (Hanjin, 2018).

In the above figure are represented the main ecomanagement activities of $\mathrm{CO}^{2}$ reduction integrated by Hanjin Shipping in their environmental management system.

Network management activities consist in route optimization and reducing in vessel speed through eco steaming. Fleet management activities considers vessel size (average TEU), optimization in chartered vessels ratio and in age of vessels. Vessel operation and performance management refers to making efficient vessel operations, fuel and vessel performance management and improvements in port productivity management. New technology application includes application of new technology to new ships and to existing vessels (Hanjin, 2012).

\subsection{Green Management}

In 2010, the company made available the "Beyond the Ocean" Sustainability Report containing information on green management performed the period 2009-2010. Hanjin Shipping has strived to become an environmentallyfriendly logistics provider in line with the current low-carbon green growth initiative.

On January 1, 2010, the Green Management Part was established under the control of the Corporate Planning Team. This department oversees and implements numerous strategies, including strategic compliance, managing a green supply chain, building a green reputation and stimulating green growth. The main objective of Strategic Compliance is to monitor domestic and international regulations and trends regarding greenhouse gas emissions, represent our company in all legislative procedures and comply with all relevant climate change regulations. Managing a Green Supply Chain refers to the procedures of transparently calculating, monitoring and consistently reducing GHG emissions from their vessels, terminals and office buildings. In this regard, Hanjin Shipping has developed and implemented various effective and convenient systems, such as the "Green House Gas Monitoring System" and "Supply Chain Carbon Calculator" (SCCC).

In December 2012, Hanjin Shipping and Marine Research Institute of Samsung Heavy Industries signed an agreement to perform joint research on ship energy efficiency management and with the aim of building highefficiency ships to regulate $\mathrm{CO}^{2}$ emissions. In today business environment, it has become critical to ensure efficient operations and reduce operating costs and the research agreement is meant for application of Vessel Portal Service - System to be applied to 4,600 TEU-class container ships, reducing fuel consumption by up to 15\% (Hanjin, 2018).

\subsection{Greenhouse Gas Inventory System}

In 2010, Hanjin Shipping introduced the Greenhouse Gas Inventory System for the integrated control of carbon emissions arising from business activities. The system collects data regarding carbon emissions by source and calculates the total carbon emissions of the company in order to establish the base year and carbon emission reduction goal. Hanjin Shipping transparently discloses information regarding our carbon emissions to stakeholders. Total emissions were the lowest in 2009 due to a decrease in cargo volume brought about by the market conditions of the shipping industry. With the shipping industry recovering in 2010, emissions from vessels totalled 9.67 million tons. Approximately 99\% of Hanjin Shipping's GHG emissions come from the operation of their ships. In regards to terminals, emissions from Busan New Port accounted for $25 \%$, while the Yoido office building emitted $33 \%$ of the total emissions from company buildings.

\subsection{Supply Chain Carbon Calculator}

Hanjin Shipping was the first company in the global shipping industry to offer customers use of a Supply Chain Carbon Calculator on their website (www.hanjin.com), allowing them to calculate the carbon emissions of their 
intended container transportation by period, multiple routes, and bill of landing (BL). In May 2011, new functions were added so that calculations can be customized by BL or by a shipper's own data. The calculation formula for marine routes is based on guidelines provided by the Clean Cargo Working Group, with $\mathrm{CO}^{2}$ index data verified by DNV (Det Norske Veritas), a respected independent foundation with the purpose of safeguarding life, property, and the environment.

\section{5. “Eco Management” Programme}

The "Eco Management" programme of Hanjin Shipping aims to reduce fuel oil and $\mathrm{CO}^{2}$ emissions, to assist in the prevention of global warming. In October 2007, Hanjin set up a fuel management Task Force team.

The company built a management system which enables to easily monitor fuel consumption and analyze the economy of shipping services ships by route. The system provides 20 tasks in areas of shipping services, efficiency and fuel supply, where it focuses its attention. In March 2013, the company organized a committee to examine fuel reduction and through a range of efforts - such as broad practice of BSP (Bunker Saving Program), rationalization of route, reduction of sea speed, etc - some 105,000 tons of fuel oil and 330,000tones of $\mathrm{CO}^{2}$ emissions have been reduced in the first half of the year. In addition, Hanjin fitted new technology to its new buildings, including AMP (Alternative Maritime Power) equipment and eco-electric control engines, with higher fuel combustion efficiency. This eliminates air pollution emissions while at anchor. It is also using silicon paints, to reduce hull resistance, which also reduces fuel.

In this way, Hanjin Shipping's Eco Management is reducing $\mathrm{CO}^{2}$ emissions reflecting the company's ongoing commitment to solving environmental problems and to underline its position as a leading ecomanagement global company (Birkman et al., 2010).

\section{Conclusion}

A solution to the environmental issues would be for shipping companies to revisit and act environmentally by developing ecomanagement structures, led by ecomanagers. Besides protecting the environment, ecomanagers aim to minimize the amount of waste by reducing energy consumption and making more efficient use of resources in order to make cost minimization.

The motivation for adopting ecomanagement resides not only in complying with the international environmental directives and regulations, nor to comply with demands of clients and suppliers. Implementing ecomanagement should be promoted due to awareness of the economic development's environmental impact for the actual and following generations. In order to become and behave as an ecomanager, a manager should express the intention to conduct economic activities with care and responsibility. However, the concept of ecomanagement is still under-researched and questionnaire issue in the maritime industry. The rationale behind are that the annual international conferences on climate change (i.e., United Nations Framework Convention on Climate Change Conference of the Parties) remains little progress, as well as the industrialized nations who are actually the key polluters demonstrate a reduction in their commitments and awareness of the climate change knowledge (Mgbemene et al., 2016).

The Hianjin Shipping case study provides a good example of implementing ecomanagement by a shipping company. There are enlisted the specific actions taken while implementing ecomanagement thinking and attitude in the maritime business. Described actions are based on optimization of network management, improvements in fleet management, vessel operation and performance management, as well as investments in new technology applications. An ecomanagement attitude leads to savings, improvement of the company's status and image in the community, long term profit increase and not ultimately and in an absolute sense, business excellence. Creation of awareness of the influence of the activities with respect to climate change should be implemented and urgently requires more understanding. We believe that this study can provide a platform and theoretical knowledge for the policy makers, shipping companies, government bodies and logistics associations to develop a comprehensive ecomanagement framework in the future. This paper provides a preliminary study in the ecomanagement concept. In the future, we will develop a large-scale empirical study across the global so as to increase the generalization of the study and provide concrete solutions to the maritime industry and international bodies in the future. 


\section{Appendix A. Supplementary material}

Supplementary data associated with this article can be found, in the online version, at https://jsdtl.sciview.net

\section{Funding}

The authors received no direct funding for this research.

\section{Citation information}

Dragomir, C., \& Lau, Y.-Y. (2018). Investigating the next generation of managers - the ecomanagers. Journal of Sustainable Development of Transport and Logistics, 3(2), 82-89. doi:10.14254/jsdtl.2018.3-2.6.

\section{References}

Birkman, J., Garschagen, M., Kraas, F., \& Quang, N. (2010). Adaptative urban governance: New challenges for the second generation of urban adaptation strategies to climate change. Sustainability Science, 5(2), 185-206.

Bojar, E. (2012). Eco-management in Polish Companies. Problems of Sustainable Development, 7(2), 107-113.

Boron, S.,\& Murray, K. (2004). Bridging the Unsustainability Gap: a Framework for Sustainable Development.Sustainable Development, 12, 65-73.

Crutzen, P. (2011). The Anthropocene: Geology by Mankind, Coping with Global Environmental Change, Disasters and Security. Hexagon Series on Human and Environmental Security and Peace, 5, 3-4, Springer Publisher, New York: United States.

Dalal-Clayton, B.,\& Bass, S. (2002). Sustainable Development Strategies: A Resource Book. OECD.

Dasgupta, P. (1993).An Inquiry into Well-Being and Destitution. Oxford: Clarendon Press.

Drexhage, J., \& Murphy, D. (2010). Sustainable Development: From Brundtland to Rio 2012. High Level Panel on Global Sustainability, United Nations Headquarters, New York.

Hanjin (2012).Global Logistics Leader. Hanjin Shipping Brochure, 32-33.

Hanjin. (2018).Retrieved July 6, 2018, fromhttp://www.hanjin.com.

IEMA. (2018). Transforming the World to Sustainability. Retrieved July 6, 2018, from http://ems.iema.net/emas.

International Organization for Standardization. (2018). Retrieved July 6, 2018, from http://www.iso.org/iso/home/standards/management-standards/iso14000.htm.

Jackson, T., \& Michaelis, L. (2003). Policies for Sustainable Consumption. Sustainable Development Commission: London.

Lau, Y.Y. (2018). An Empirical Study of Shipping Networks. $1^{\text {st }}$ Ed., Lambert Academic Publishing, Saarbrücken: Germany.

Mgbemene, C.A., Nnaji, C.C., \& Nwozor, C. (2016). Industrialization and its backlash: focus on climate change and its consequences. Journal of Environmental Science and Technology, 9(4), 301-316.

Năstase, C., \& Popescu, M. (2007). Sustainable Development through the Resource Use - Regional Innovation System. Proceedings of the 3rd IASME/WSEAS International Conference on Energy, Environment, Ecosystems and Sustainable Development, Agios Nikolaos, Greece.

Ng, A. K. Y., A. Becker, S. Cahoon, S. L. Chen, P. Earl, \& Yang, Z. (2016). Time to act: The criticality of ports in adapting to the impacts posed by climate change. In Climate change and adaptation planning for ports, eds. A.K.Y. Ng, A. Becker, S. Cahoon, S. L. Chen, P. Earl, and Z. Yang, 1-8. Abingdon: Routledge.

Ng, A.K.Y, Zhang, H., Afenyo, M., Becker, A., Cahoon, S., Chen, S.L., Esteban, M., Ferrari, C., Lau, Y.Y., Lee, P.T.W., Monios, J., Tei, A., Yang, Z.,\&Acciaro, M. (2018). Port decision maker perceptions on the effectiveness of climate adaptation actions. Coastal Management, 46(3), 148-175.

Pritchard, B. (2000).The Organisation of a Shipping Company. Galvagnon/Pearson, ENMM, Marseille, 4-5.

Shipping Herald. (2018). Retrieved July 7, 2018, fromwww.shippingherald.com. 
The American Heritage Dictionary of the English Language. (2000). Fourth Edition, Houghton Mifflin Company.

United Nations World Commission on Environment and Development. (1987).Report of the World Commission on Environment and Development: Our Common Future. Oxford University Press: University of Oxford.

Wang, L., Notteboom, T., Lau, Y.Y., \& Ng, A.K.Y. (2017). Functional differentiation and sustainability: a new stage of development in Chinese container port system. Sustainability, 9(3), 328-343.

Wilhelmsen. (2018).Retrieved July 7, 2018, from http://www.wilhelmsen.com.

WWF (2012). Shipping and Sustainability, United Kingdom, March 2012

Yang, Z., Ng, A.K.Y., Lee, P.T.W., Wang, T., Qu, Z., Rodrigues, V.S., Pettit, S., Harris, I., Zhang, D., \& Lau, Y.Y., (2018). Risk and cost evaluation of port adaptation measures to climate change impacts. Transportation Research Part D, 61, 444-458.

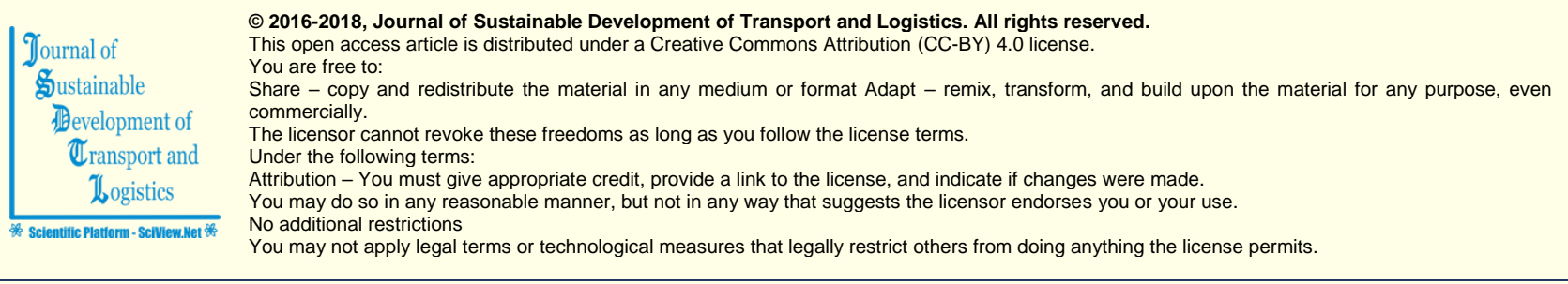

Journal of Sustainable Development of Transport and Logistics (ISSN: 2520-2979) is published by Scientific Publishing House "CSR", Poland, EU and Scientific Publishing House "SciView", Poland, EU

Publishing with JSDTL ensures:

- Immediate, universal access to your article on publication

- High visibility and discoverability via the JSDTL website

- Rapid publication

- Guaranteed legacy preservation of your article

- Discounts and waivers for authors in developing regions

Submit your manuscript to a JSDTL at https://jsdtl.sciview.net/ or submit.jsdtl@sciview.net 